\title{
Villous Adenoma Coexisting with Non-Muscle Invasive Urothelial Carcinoma of the Bladder, Case Report
}

\section{Kas Invazyonu Göstermeyen Invaziv Ürotelial Karsinomla Birlikte Görülen Mesanenin Villöz Adenomu, Olgu Sunumu}

\author{
Bahar Akkaya MD1, Gülden Tasova-Yılmaz MD1, Hampar Akkaya MD2, Mustafa Faruk Usta MD3 \\ ${ }^{1}$ Akdeniz University Faculty of Medicine, Department of Pathology, Antalya, Turkey \\ 2Bașkent University Faculty of Medicine, Department of Pathology, Antalya, Turkey \\ ${ }^{3}$ Akdeniz University Faculty of Medicine, Department of Urology, Antalya, Turkey
}

\begin{abstract}
Summary
Occurrence of villous adenomas arising in the urinary tract is uncommon. They have been reported usually in the gastrointestinal tract. We reported a case of urinary bladder villous adenoma coexisting with urothelial carcinoma in a 72-year-old male. The patient underwent trans urethral resection because of diagnosis villous adenoma and non-muscle invasive urothelial carcinoma. Over the past twenty-nine months of follow up, the patient is alive and developed no metastasis. Patients with isolated villous adenomas in the urinary bladder have an excellent prognosis and surgical resection is curative. However, it is uncertain whether an untreated lesion might eventually develop into an adenocarcinoma. Therefore, close follow up is recommended because of the possibility that this condition might be premalignant.

Key Words: Villous adenoma, urinary bladder neoplasm, adenoma
\end{abstract}

\section{Özet}

Üriner sistemden kaynaklanan villöz adenom gelişimi nadirdir.Genellikle gastrointestinal sistemde rapor edilir. Biz 72 yaşındaki erkek hastada ortaya çıkan, ürothelial karsinomla birliktelik gösteren mesane villöz adenomu olgusunu sunduk. Hastaya mesanenin villöz adenomu ve ürotelial karsinomu tanısıyla trans üretral rezeksiyon yapılmıştı. Hasta son 29 aydır takipte olup hayattadır ve metastazı yoktur. Mesanenin izole villöz adenomuna sahip hastaların prognozu mükemmeldir, cerrahi rezeksiyon küratiftir. Bununla birlikte tedavi edilmemiş hastalardan adenokarsinom gelişip gelişmeyeceği kesin değildir.

Anahtar Kelimeler: Villöz adenoma, mesane neoplazisi, adenom

\section{Introduction}

Although villous adenomas commonly arise in the gastrointestinal tract, villous adenomas of the bladder are uncommon $(1,2)$. There are a few cases in the literature. They should be accepted as important lesions because the malignancy potential of them is still not known. We report an additional case of a villous adenoma coexisting with non-muscle invasive urothelial carcinoma of the bladder.

\section{Case Report}

A 72-year old patient was admitted to hospital with the complaint of non-coagulated hematuria and pain. There was no remarkable finding in physical examination. Cystoscopic examination revealed two papillary tumors in the urinary bladder. Larger one measuring $25 \mathrm{~mm}$ was on the dome of bladder and the other was $16 \mathrm{~mm}$ mass in the left wall of urinary bladder, with enhancement. Cold punch biopsy was performed at cystoscopic examination. Histopathology confirmed that the resected one tumor was a villous adenoma, and the other was non-muscle invasive urothelial carcinoma. TUR was performed after punch biopsy. Each tumor was resected and diagnosed, respectively. Histopathology confirmed that the mass was a villous adenoma with a polypoid growth of the glandular epithelium consisting of small tubular glands, dilated cystic glands or papillary fronds lined by a columnar epithelium and including goblet cells. Intracellular and extracellular mucin was seen. Epithelial cells displayed mild nuclear atypia and nuclear pseudostratification suggestive of severe dysplasia. No invasive component was found in the villous adenoma (Figure 1). Immunohistochemical analysis of the polypoid lesion showed that the epithelial cells were diffusely positive for cytokeratin 20 (CK20), focally positive for cytokeratin 7 (CK7), carcinoembryonic antigen (CEA) and mucin 2 (MUC2). Non-muscle invazive urothelial carcinoma was identified the other side of urinary bladder (Figure 2). Based on the pathological findings, the patient was diagnosed with a rare case of villous adenoma of the bladder and non-muscle infiltrative urothelial carcinoma arising in the bladder. After BCG therapy, he has been followed by cystoscopic examination for every three months. Over the past 29 months of follow up no local recurrences were detected. 


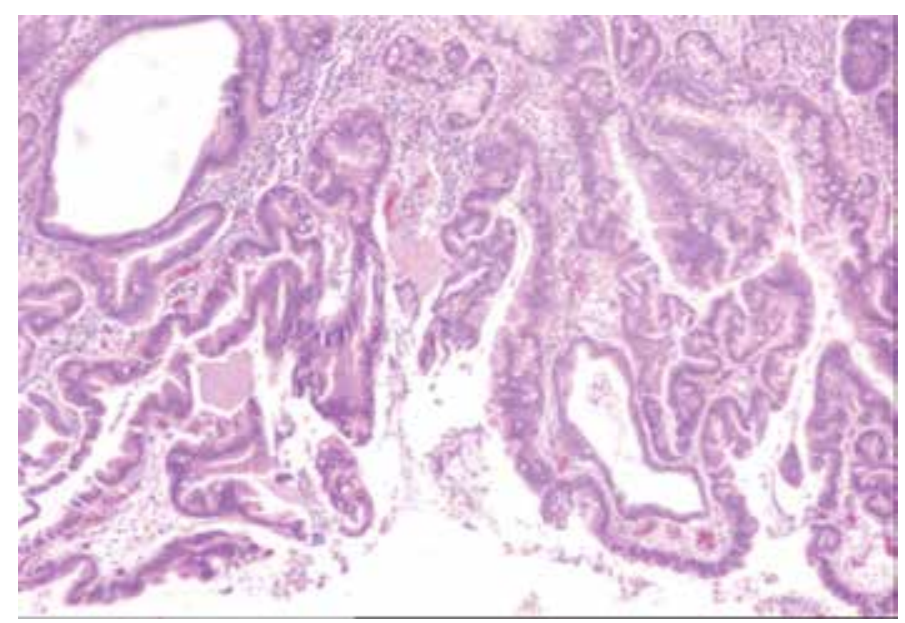

Figure 1. Papillary fronds covered by intestinal type columnar epithelium, and including goblet cells, intracellular and extracellular mucin (H\&E; x100)

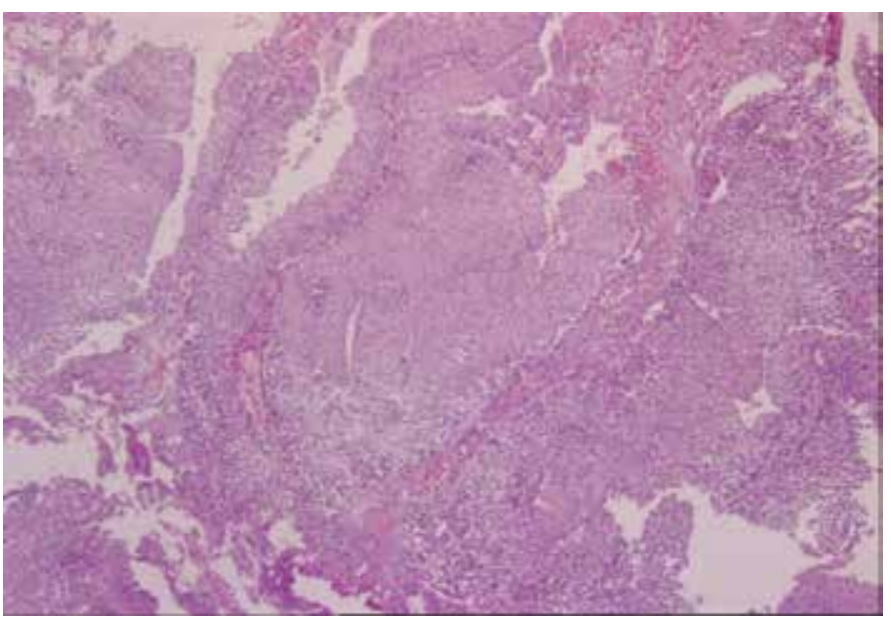

Figure 2. Non-muscle infiltrative urothelial carcinoma (H\&E; $\mathrm{x} 100)$

\section{Discussion}

Villous adenomas of the urinary tract, including the bladder, are infrequently encountered. Our case in which the villous adenoma coexists with urothelial carcinoma is the third case report in pub-med. Villous adenomas are found predominantly in the middle aged and senile man. The mean is 57 years of age with the range from 33 to 79 (1). Our patient was a 72 year old man. The most common site of its occurrence is the bladder dome and posterior wall, our case located on the dome of the bladder. The frequent complaints were hematuria, irritative symptoms and rarely mucusuria $(2,3,4)$.

Villous adenomas are rare in comparison to adenocarcinomas, with only fourteen individual cases having been reported so far. Morphologically, urinary tract villous adenomas are identical to colonic villous adenomas. They both exhibit rounded projections of pseudostratified columnar epithelium with goblet-type mucin-producing cells and the nuclear atypia is variable. The immunohistochemical profile of these two entities is also similar with positive findings for cytokeratin 20 and usually negative findings for Epithelial Membrane Antigen (EMA) staining in most cases. Consistently with the literature, our sections stained strongly and diffusely positive with CEA. In contrast to intestinal lesions, however, about $50 \%$ of cases of the urinary tract villous adenomas exhibit positive results for cytokeratin 7. Molecular studies performed in one case of bladder villous adenoma showed DNA aneuploidy and increased expression of $p 53$. Expression of p53 in the villous adenoma suggests that a genetic progression from a colonic adenoma to a carcinoma may be responsible for the development of a villous adenoma of the bladder. There may be a similar spectrum of changes in the bladder, progressing from metaplasia in cystitis glandularis, to dysplasia in a villous adenoma, and eventually to malignant change in an adenocarcinoma. As so few cases have been reported, it is difficult to predict their behaviors, or assess their potential for malignant transformation $(3,4,5,6,7)$.

Once villous adenoma has been diagnosed, it is important to eliminate the presence of invasion. Superficial muscle coat is not as well defined and therefore the presence of invasion is more difficult to assess. Subjective features, such as the degree of dysplasia and surrounding stromal reaction, must be used. The differential diagnosis of a villous adenoma includes florid cystitis glandularis and a well-differentiated adenocarcinoma. The former does not have the well-formed villous structures that are typical of the villous adenoma. In the latter, the epithelium is pseudostratified, and the nuclei are enlarged, crowded and hyperchromatic, features that are not present in cystitis glandularis $(2,3,8,9,10)$. The coexistence of villous adenoma with in situ or invasive adenocarcinoma, squamous cell carcinoma, and urothelial carcinoma was reported in some studies $(3,4)$. On the other hand, there is no clear evidence about progression to carcinoma, in spite of its colonic counterpart (1).

Patients with isolated villous adenomas in the urinary bladder have an excellent prognosis and surgical resection is accepted as curative. Since it is a rare lesion, there are no exact data about follow-up and recurrence. However, it is uncertain whether an untreated lesion might eventually develop into an adenocarcinoma. Therefore, close follow up is recommended because of the possibility that this condition might be premalignant $(7,9)$. So the clinician and the pathologist should be aware of this situation. There were no specific findings on ultrasonography, CT, MRI or cystoscopic examination. Therefore, pre-pathological villous adenoma of the bladder is extremely difficult to diagnose. Adequate sampling and pathological evaluation of specimens are recommended in order to exclude the possibility of adenocarcinoma based on the grade of atypia and presence of invasion. There are some case reports of solitary villous adenoma in the bladder or with coexisting adenocarcinoma. However, to the best of our knowledge, this is only the third report of villous adenoma in the bladder of coexisting with urothelial carcinoma that has been published in the literature.

Concept: Bahar Akkaya

Design: Bahar Akkaya, Gülden Taşova Yılmaz

Data Collection or Processing: Gülden Taşova Yılmaz, M. Faruk Usta

Analysis Interpretation: Bahar Akkaya

Literature Search: Gülden Taşova Yılmaz, Hampar Akkaya 
Writing: Hampar Akkaya

Conflict of Interest: No conflict of interest was declared by the authors.

Financial Disclosure: The authors declared that this study has received no financial support.

\section{References}

1. Sung $W$, Park $B D$, Lee $S$, et al. Villous adenoma of the urinary bladder. Int J Urol 2008; 15:551-553.

2. Ratanarapee S, Uiprasertkul M, Pradniwat K, et al. Villous adenoma of the urinary bladder: a case report. J Med Assoc Thai 2010;93:1336-1339.

3. Nakamura Y, Orikasa K, Fujishima F, et al. A case of villous adenoma of the urinary bladder with tubulovillous architecture: characterization by immunohistochemical analysis. Pol J Pathol 2011;62:179-182.
4. Atik $E$, Akansu B, Davarci $M$, et al. Villous adenoma of the urinary bladder: rare location. Contemp Oncol (Pozn) 2012;16:276-277.

5. Chaudhuri A, Sandhu DP, Xuereb J. Villous adenoma of the urinary bladder. BJU Int 1999;84:177-178.

6. Daroca PJ Jr, Mackenzie F, Reed RJ, et al. Primary adenovillous carcinoma of the bladder. J Urol 1976;115:41-45.

7. Cheng L, Montironi R, Bostwick DG. Villous adenoma of the urinary tract: a report of 23 cases, including 8 with coexistent adenocarcinoma. Am J Surg Pathol 1999;23:764-771.

8. Channer JL, Williams JL, Henry L. Villous adenoma of the bladder. J Clin Pathol. 1993;46450-452.

9. Seibel JL, Prasad S, Weiss RE, et al. Villous adenoma of the urinary tract: a lesion frequently associated with malignancy. Hum Pathol 2002;33:236-241.

10. Corica FA, Husmann DA, Churchill BM, et al. Intestinal metaplasia is not a strong risk factor for bladder cancer: study of 53 cases with long-term follow-up. Urology 1997;50:427-431. 